\title{
Description of Yakut culture in Russian in texts of different genres
}

\author{
Akulina Vasil'eva* \\ North-Eastern Federal University, Institute of Languages and Cultures of the Peoples of the North-East, 58, Belinskogo street, \\ Yakutsk, 677000, Russia
}

\begin{abstract}
Describing a culture by means of another language is a large and interesting translation task. Nowadays, this eternal problem becomes more and more relevant for traditional cultures since the quality of the transmitted verbal information about unique culture-specific elements also depends on the accuracy of their description. The Russian language for the peoples of the Russian Federation is the language of interethnic communication, and translating folklore and literary texts, as well as writing scientific works in Russian on the Yakut culture, allows other peoples to discover the Yakut culture. Over the four centuries of Yakut-Russian contacts, many texts describing the Yakut culture have been created in Russian. In this research, the source material is three different texts: a translation of a heroic epic, a translation of a work of fiction, and an ethnographic description of a native speaker of the Yakut language and culture written in a non-native Russian language. These texts contain the same culture-specific elements that are translated differently depending on the target audience. In the course of the research, we have found that the culturespecific elements of the Yakut culture are mainly transliterated, and commentaries on them can be different in exhaustiveness and depth. In addition, we note that traditional loan translations from the Yakut language have been established to translate various epithets and set expressions associated with folklore and mythology. Such expressions often seep into scientific texts on ethnography because traditional crafts and traditional life, in general, are inextricably linked with the spiritual culture of the people.
\end{abstract}

\section{Introduction}

Professor and Doctor of Philological Sciences Victor V. Kabakchi founded a new branch of linguistic in Russia interlinguoculturology. He has been researching features of the description of Russian culture in English-language texts since the 1970s-1980s. In this branch, he examines the following aspects of the description of Russian culture in English-language texts: 1) ways of naming the elements of Russian culture, 2) specificity of structuring a text of secondary cultural orientation, 3) ways of stylizing a text to preserve its Russian identity as much as possible, 4) features of intercultural communication ethics, etc. [1]

We have applied Victor V. Kabakchi's classification to the pair 'Yakut and Russian linguocultures' and determined the following aspects in the target translated texts of folklore (or ethnographic) content. The first is ways of naming the elements of Yakut culture with the means of Russian language, i.e., the methods of communicating culture-specific words. The second is ways of commenting ethnographic information as within a translated text as outside of it, i.e., specificity of structuring a text of secondary cultural orientation depending on practical conditions. The third is ways of stylizing a text in the Russian language to preserve its Yakut identity, i.e., replicating the lexical-grammatical structure of a text that recreates originality of Yakut poetic style through the Russian language.

Over four centuries of linguistic and cultural contacts of the Yakut people with the Russians, many written texts were created that describe Yakut culture in Russian. This rich experience opens up a wide field for comparative research in linguistic and cultural studies. Depending on the development of linguistics and translation experience, the approaches to the description of Yakut culture with the Russian language gradually changed. With the increase in the volume of translated text on Yakut culture, a variety of deliberately chosen translation strategies also appeared. For example, only since the $20^{\text {th }}$ century, translators and specialists that describe culture have begun to focus on the needs of different audiences of their texts. Different variants of naming and describing the same object or phenomenon of Yakut culture began to appear - for readers of different levels of knowledge in the culture of indigenous peoples. The identification and classification of such variants of naming and describing culturespecific elements are of great interest to modern practicing translators. Firstly, these names/terms and descriptions/commentaries can be collected into one comprehensive source so that a young translator can choose an option suitable for his translation purposes. Secondly, other researchers can compare these

*Corresponding author: vaaperevod@mail.ru 
descriptions, combine, supplement or clarify and then describe Yakut culture without confusing their readers.

\section{Materials and methods}

For this research, we chose several texts that had been translated with the use of different strategies and for readers with various levels of linguacultural expertise. The first is academic translation of the Yakut heroic epic olonkho that are a reliable source on Yakut ethnography, folklore, and language. The second is ethnographic descriptions in Russian, compiled by native speakers of the original linguistic culture, who are not philologists. The third is literary translations for a non-specialist audience.

Translations of Yakut folklore texts have been published from the very beginning of explorations of the North-East of Siberia - from the $18^{\text {th }}$ century. But early translations were most often retellings of fairy tales, legends, and the heroic epic of olonkho. For example, the first mention of the performance of olonkho and a summary of its plot in Russian is found in the travel notes of Alexander von Middendorff, a traveler and explorer of the eastern outskirts of the Russian Empire, published in St. Petersburg in 1878. Several large, detailed descriptions of the life and culture of the Yakuts were published before the 1917 revolution: for example, the books by Richard Maack "Vilyuisky District Yakut area" (1887), Wacław Sieroszewski "Yakuts. The experience of ethnographic research" (1896), Ivan Khudyakov "Verkhoyansk collection" (1890), etc. These books are different from other sources. Firstly, they were written not by members of Yakut culture but by people of other cultural identities, who learned the spoken Yakut language in a short time. Secondly, they were written before the official Yakut script appeared, so the authors wrote them as they heard, resulting in inconsistencies in transcription. Thus, it is sometimes difficult for a modern reader to immediately understand some parts of these books. Nonetheless, prerevolutionary texts are of great value as they describe the material and spiritual culture of our 19th-century ancestors.

The modern, observable period of translations of Yakut folklore starts in 1945. In 1945, a bilingual book "Nyurgun Bootur the Swift" was published in Yakutsk. It is a Russian translation of Yakuts' most famous and beloved olonkho. It was translated by folklore scientist Georgy Ergis. The translation is notable for its philological accuracy, bordering on a literal translation. But this way, the originality of the descriptions and style of the Yakut heroic epic has been preserved. The book is accompanied by extensive commentary on culturespecific words and mythological concepts. After that, similar accurate translations with a large scholarly apparatus were made for all genres of Yakut folklore. In Soviet times, the Institute of Language, Literature, and History of the Northern Branch of the Academy of Sciences of the USSR was engaged in this laborious work. And now, the successor of the said institute Institute for Humanities Research and Indigenous
Studies of the North of the Siberian branch of the Russian Academy of Sciences - is engaged in bilingual editions of Yakut folklore for scientific study.

For our research, we have chosen a translation of this institute - olonkho "Mighty Er Sogotoh". A group of folklorists who are very good at both the Yakut and Russian languages (Sardana Oyunskaya, Prokopy Efremov, and Nikolai Emelyanov) conducted the said translation in the early 1990s. The book was published in the series "Folklore of the peoples of Siberia and the Far East" in 1996. The publishers of the series set a goal for the translators "... to accurately capture and convey the essence of poetic thought in Russian in the most appropriate verbal formulation of the original. An obligatory requirement for the translation is a combination of accuracy with accessibility to a nonspecialist audience..." [2]. And this book fully satisfies this goal - it is a typical Yakut heroic epic, and the translation is understandable not only for specialists in language and ethnography but also for a non-specialist audience. This translation is not an adaptation, but it is not a literal translation either. We hold the quality of this Russian translation in high esteem.

The second book we have chosen for this research is a scientific text of Svetlana Petrova, a professional ethnographer [3]. She is a native speaker of the Yakut language and a member of Yakut culture as well as a researcher of antiquity. In other words, the subject of her books is a traditional Yakut craft, which she mastered traditionally through the lessons of her mother and grandmother, other women, who are privy to the secrets of this craft. She later made this skill of traditional sewing the subject of her scientific research. She is familiar with all the terms of this craft, which have been formed over the centuries, knows the technology and, of course, folklore and mythology associated with the craft - the meanings of ornament, shapes, and colors of products, the craft's rituals, etc. And in her books, she describes this indigenously Yakut, traditional knowledge of ancestors in another, second language - Russian, in which most of the names of objects and concepts described by her are absent.

The third book in our research is a translation of a work of fiction based on historical stories and legends of the Yakuts. The novel by the writer Dalan "Remote Vilyui" is about the adventures of the young Dagancha, who, having learned warfare from his grandfather, goes to take revenge on the murderers of his family [4]. The novel takes place before the arrival of the Russians to the Lena River. For modern people, this ancient era seems to be the freest from foreign cultural influences.

From these books, by the method of continuous sampling, we have written out words and phrases that describe Yakut culture in the Russian text: a) culturespecific items, b) elements of the folklore language that are always used when describing the Yakut antiquity. We analyzed culture-specific words for the accuracy of the transcription and the veracity of the explanations (we call them "commentaries"). To the elements of the folklore language, we attribute the conveyance of phraseological units, proverbs, and other aphorisms - for example, epic formulas of time, epithets of a person, etc., 
which in Russian texts about Yakut culture create a unique "Yakut style" and convey its archaic nature.

\section{Results and Discussion}

In the studied texts, depending on the goals and the recipients, different ways of conveying culture-specific words are used. The first is zero translation (only via transcription or transliteration), then analogous translation (selection of an analog that one way or another have similarities to a culture-specific element). The next is descriptive translation (providing the reader with a short or full explanation of a culture-specific element). In this article, we will consider analogous translation as a type of description, since this method describes a culture-specific element using an alreadyexisting image from the environment familiar to the reader.

Zero translation is used most often when translating proper names. In the Yakut-Russian translation, there are still no strict rules for transcription. Of course, the phonetics of the Russian and Yakut languages are very different, and the alphabet and graphics in both languages are Cyrillic. This complicates transcription since the same letter in both languages can denote different sounds, and the combination of particular letters, for example, diphthongs of the Yakut language, or doubled consonants, is read in Russian in a completely different way. In Soviet times, both scholars and philologists (Nikolai Samsonov, Mikhail Ivanov, etc.) and cartographers (Georgy Donidze) attempted to streamline the spelling of Yakut words in Russian texts. However, even now every translator and author of texts on Yakut culture can freely choose between transcribed and transliterated versions of the Yakut-specific element, including anthroponyms.

Having studied the source material, we have drawn up the rules for writing Yakut words in Russian texts, which we recommend to students mastering the profession of a translator. In short, these equivalents look like this. First, long vowels are transliterated, i.e. written as in the Yakut graphics, in two identical letters, except for the last syllable of the word, since the stress in the Yakut word always falls on the last syllable. Second, diphthongs are transliterated, except for the diphthong $Y \theta$, which consists of specific sounds that are absent in Russian; the indicated diphthong in the Russian text is denoted as $ю e$ ( $y u-e)$. Third, $Y$ is denoted as $ю$ $(y u), \theta$ is denoted as $o(o)$ at the beginning of a word, as $\ddot{e}$ (yo) in all other cases. Fourth, specific consonants are represented by constant equivalents: $5-2(g), h-c(s)$, $H b-H(n), \partial b-\varkappa(d j)$. Fifth, a specific consonant letter $\mathrm{H}$ between two vowels is transcribed as нг $(n g)$, in other cases it is replaced by $\mu(n)$. Of course, these equivalents may be erroneous, or they may not be able to overcome the well-established tradition of writing Yakut words in Russian texts, so the work on identifying phonetic similarities and dissimilarities continues.

Regarding traditions, it should be noted that the Cyrillic alphabet forces us to use transliteration. For example, in words blcblax (ysyah) we use instead of ыхех (yheh), Джырыбына Джырыльатта (Jyrybyna Jyrylyatta) instead of Дирибина Дирилетта (Diribina Diriletta), etc. Seeing words like blcblax (ysyah) or Джырыбына Джырылыатта (Jyrybyna Jyrylyatta) in the Russian text, a reader familiar with these concepts from other texts can immediately understand what it is about and compare the new information with the texts already familiar to them. On the contrary, if we introduce a new spelling of such words, even with almost impeccable transcription, the readers will need to establish correspondences to these words in the early texts, which would be tedious. And a second remark on this matter: if texts about Yakut culture are translated into other languages, then the source of transcription of culture-specific elements should be the pronounced speech of a native speaker, and not the Russian written text, although, unfortunately, it is what most often happens now.

When comparing the ratio of transcription and transliteration in our source material, we found the following pattern. Transliteration is typical of the translation made by the team of the Institute for Humanities Research and Indigenous Studies of the North of the Siberian branch of the Russian Academy of Sciences, as it is important for correlating culturespecific elements with previously published texts. Having familiarized ourselves with other translations of the Institute, we can assert that transliteration takes up a substantial part in them. Transliteration is also typical for the description of Yakut culture by its bearers. For example, transcription prevails in Svetlana Petrova's text. Moreover, the author often introduces into the text the Yakut spelling of culture-specific elements (particularly, craft terms), using letters that are not in the Russian alphabet but are in the Yakut Cyrillic alphabet, to denote the specific sounds of the Yakut language - $\theta$, $Y, H, h, 5$. It may indicate not only the lack of translation competencies of the ethnographer but also the desire to accurately transfer terms following previously published texts. Also, it may be that the author thinks that her book will be of interest only to native speakers of the Yakut language. In literary translation, we noticed more cases of transcription, although transliteration plays a leading role here as well. The reason, in our opinion, is the same - the desire to preserve traditional transliteration in conditions of identical alphabets so that culture-specific elements are recognizable in each text.

Composing commentaries on the texts of folklore and fiction in the Yakut-Russian translation is an important part of the translator's work. Most often, such commentaries are a look at Yakut culture from the inside. It is a description of the native culture in the second language - the target language. On the other hand, other specialists are also involved in the description of Yakut culture in Russian, and their works are also translated into Russian or originally written in Russian. For example, scientific and popular science works on arts and crafts, folk music, dance, etc.

In our source material, commentaries on culturespecific elements were of three types: 1) simplified explanation included in the translation text next to the transcription of a culture-specific element, 2) using in 
translation only explanations of a culture-specific element, without transcription, 3) a short or more extensive commentary outside the translation text. The commentaries of the first group are the most common in all three types of texts describing Yakut culture. Of course, there are more of them in a literary text, for example, удалеи-хосуун (daring-hosuun), богиня деторождения Aüblblcblm (goddess of childbirth Aiyysyt), or "Муус Тонот кэмэ тиийэн кэлбитэ. Пришло время Муус Тонгот - время Ледяного Hacma" (Time has come for Muus Tongot - time of Ice Crust) [4]. They are also found in the description of the craft: оберегающее украшение - дьайаа (protective adornment - djaiaa); “...бисером вышивалась прямая линия - тонођос ойуу, сис ойуу (букв, узорпозвоночник)" - “...a straight line was embroidered with beads - tonogos oiuu, sis oiuu (verbatim spine pattern)". In the academic translation of the epic olonkho "Mighty Er Sogotoh" all culture-specific elements are indicated either in italics or by an asterisk, which means there is a commentary on them at the end of the book.

Commentaries of the second group are rare. Of the three books studied, we found such a translation several times in olonkho - for example, when translating the culture-specific element kuochai tumusahtara: «Когда мимо мысов, где кровавые жертвы приносят...» ("When passing by the capes, where bloody sacrifices are made ..."). The translation of this culture-specific element is indicated by an asterisk. Therefore, we refer to the commentaries at the end of the book and read the following explanation outside of the translation text: «Когда мимо мысов, где кровавые жертвы приносят... (куочай тумуһахтарын туораталаан) имеется в виду место жертвоприношения злым духам, наславшим болезни; когда забивают жертвенную скотину в лесу, шкуру с головой, рогами и копытами вешают на дерево, на него же помещают деревянный указатель дороги - куочай, имеющий вид стрелы, острый конец которого направлен в ту сторону, где, по поверью якутов, живут злые духи, которым предназначена жертва. Обычно на юг, запад либо восток. Считалось, что наиболее сильные духи обитали именно в этом направлении, а не на севере» ("When passing by the capes, where bloody sacrifices are made ... (kuochai tumusahtaryn tuoratalaan) - refers to the place of sacrifice to evil spirits who sent diseases when sacrificial cattle are slaughtered in the forest, their skin with the head, horns, and hooves is hung on a tree, and a wooden road sign is placed on it - kuochai, which looks like an arrow, the sharp end of which is directed towards where, according to the Yakut belief, evil spirits live, to whom the sacrifice is intended. Usually towards south, west, or east. It was believed that the most powerful spirits lived in this direction and not in the north") [2]. Thus, thanks to an exhaustive commentary on the culture-specific element, an ethnographer can form a complete picture of the situation described in the olonkho and compare this information with the mythology of other peoples.

In translations, one can often find many explanations of culture-specific elements as footnotes, dictionaries, commentaries, i.e. outside the text. However, in the literary translation of "Remote Vilyui" there was not a single explanation outside of the text. It may be because the translation was intended for the teenage audience of the entire multinational Soviet Union. All culturespecific elements have explanations within the text - for example: «...жилье, в котором они сейчас так уютно сидели, построено из ошкуренных бревен, покрыто сверху корьем и обмазано глиной, это - хатырык балаган, то есть юрта из корья...» (“... the dwelling in which they were now sitting so comfortably was built on sanded logs, covered with bark on top and clayed - it is a hatyryk balagan, or a yurt made of bark...") [4]. And the concept of ysyah in this text appears as a "celebration" - without the transcribed culture-specific word. From the context of the dialogue about ysyah, it is clear that this Yakut festival is held in summer and is associated with shamanic rituals, so it has a religious significance. In the scientific text of Svetlana Petrova, the culture-specific element of ysyah is also explained inside the text: «...культовый праздник ысыах, главная идея которого - сохранение порядка в природе, мира среди людей...» (“... the cult holiday of ysyah, the main idea of which is the preservation of order in nature, peace among people...") [3]. The out-oftext commentaries in this ethnographic text are presented as a dictionary of terms and concepts of national sewing and include about 150 words. In the academic translation of olonkho, the same concept of ysyah is explained in an out-of-text commentary: «Ысыах (ыһыах) национальный праздник якутов, устраиваемый в начале лета и сопровождаемый танцами, игрищами и кумысным питьем. В прошлом ысыах устраивали по случаю свадьбы и других важных событий. В олонхо ысыах устраивают по поводу важнейших событий (победа героя, женитьба богатырей и т.п.), но обязательно приуроченных к лету. В настоящее время ысыах является всенародным национальным праздником» ("Ysyah (ыhыах) is a national holiday of the Yakuts, held at the beginning of summer and accompanied by dances, merrymaking, and kumis drinking. In the past, Ysyah was held on the occasion of weddings and other important events. In olonkhoб ysyahs are arranged for the most important events (the victory of a hero, the marriage of heroes, etc.), but always timed to coincide with the summer. Currently, Ysyah is Yakut's national holiday") [2]. In these examples, we see a wide variety of explanations. They are of varying exhaustiveness and depth is made in accordance with the competence of the intended audience.

The veracity and accuracy of such commentaries vary depending on the target audience. Adapted translations for children or readers who are not familiar with Yakut culture abound with commentaries of analogous translation. It is because a person perceives the new via their old experience. So for young readers to get some idea of a phenomenon of an unfamiliar culture, they need to draw an analogy with a familiar phenomenon. Translations made for specialists are almost always accompanied by more extensive commentaries that show many aspects of a culture-specific element - its origin, 
manufacturing methods, symbolic meaning, sometimes a reference to more detailed researches. Thus, commentaries as a means of constructing a text of secondary cultural orientation largely depend on the practical needs of the translator.

Modeling of the lexical and grammatical structure of a text that recreates the originality of Yakut literary texts in Russian has been used for a long time. Therefore, certain traditions have developed in the Yakut-Russian translation that allows recognizing the "Yakut style" in Russian translations. For example, there are a) paired words unexpected for the Russian reader: волшебночерный туман (magically black fog), ненасытнобуйные небеса (insatiable raging skies), гулко-цирокая высь (echoing wide heights), стремительно-гладкие белье небеса (swift smooth white skies), etc., b) stem composition hinting the unique beauty of the original's artistic speech: девятиизлучистый путь (a ninewinding path), трехлучистые глаза (three-rayed eyes), четырехраскатистый гром (a four-sided thunder), etc. The morphological method of stem composition is also widespread in the Russian language. For example, the nouns napoxod (steamship), паровоз (steam train), бензовоз (gas-tank truck), etc., as well as the notorious Soviet Newspeak. However, translators create new words by skillfully using stem composition. These new words are mostly adjectives, and due to their novelty, they are perceived by the reader as something different, not entirely Russian [5]. This technique of YakutRussian translation is also consistently used in bilingual editions of Yakut folklore, published mainly by folklorists of the Institute for Humanities Research and Indigenous Studies of the North of the Siberian branch of the Russian Academy of Sciences. For example: “Ол курдук ађыс иилээх-сађалаах, атааннаахмөнүөннээх, айгырдаах-силиктээх а5а бараан дойдубун аан бастаан со5урдук айан испиттэр эбит... (Ol kurduk agys iileeh-sagalaah, ataannaahmonuenneeh, aigyrdaah-silikteeh aga baraan doidubun aan bastaan sogurduk aian ispitter ebit...) - Вот такую: восьмиободную-восьмикрайнюю, с треволненьямибеспокойствами, в роскошном наряде-убранстве отчую почтенную страну мою изначальную вот так сотворяли, оказывается...» (Just like this: eightrimmed and eight-edged, with tribulations-worries, in a luxurious attire-adornment venerable country of mine originally was created like this, it turns out...) [2]. In literary translation, the same epic formula of the world's description is translated as follows. "АБыс иилээхсақалаах, атааннаах-мөнүөннээх Аан Ийэ дойдуга уол о5о барахсан ортотунан курданан, уһугунан дугунан сылдьарын усталаах туоратыгар оччоттон баччақа диэри эрэй бөБөнү энэринэн тэлэргэ, мун бөБөну муннунан тыырарга ананан айыллар буоллаца эбээт (Agys iileeh-sagalaah, ataannaahmonuenneeh Aan Iie doidoga uol ogo barahsan ortotunan kurdanan, usugunan dugunan syldjaryn ustalaah tuoratygar ochchotton bachchaga dieri erei bogonu enerinen telerge, myn bogonu munnunan tyyrarga ananan aiyllar buollaga ebeet). - Так было в древней древности, так ведется и поныне: добрый удалец рождается на Матушке-Земле, что о восьми концах света, восемь раз опоясанной раздорами и обуянной ссорами, чтобы на всем жизненном пути страдания цеплялись за полы его одежды и неисчислимые муки ветром летели в лицо...» (So it was in ancient times, and so it is now: an honest fellow is born on Mother Earth that has eight edges, eight times it is girthed with strife and swept with quarrels so that all his life suffering clung to the hem of his clothes and innumerable torments were blown into his face...") [4]

Among our source material, we found such methods of loan translation of a phrase's grammatical structure in literary translation and academic translation of folklore. Of course, we did not find epic descriptions of the world in a scientific publication about traditional craft, but we were able to pinpoint similar phrases of "Yakut style": «Якуты, постоянно соприкасаясь с миром стихий, хорошо знали прихоти Великой Матери-Природы и ее мощь. Именно это помогало им находить способы защиты от стихии и выживать в суровых условиях Севера. 'Дитем природы' - айьльа оқото, 'солнечным человеком' - күн киһитэ, ‘людьми солнечных лучей $c$ поводьями на спине, $c$ добросердечной мыслью' - көхсүттэн тэһииннээх, көмүскэстээх санаалаах күн сирин дьонноро называют себя якуты в своих благословенияхалгысах. Появление в традиционно-обрядовых видах одежды различных знаков и символов, имеющих магико-охранную функцию, объясняется прежде всего древними мифологическими представлениями народа. Среди прочих видов обрядовой одежды по разнообразию кроя и сложности декора, имеющего закодированные знаки и символы, выделяется комплекс свадебной одежды...» (“The Yakuts, being constantly in contact with the forces of nature, were well aware of the whims of the Great Mother Nature and her power. This knowledge helped them find ways to protect themselves from the elements and survive in the harsh conditions of the North. The Yakuts call themselves 'children of nature' (айbыльа о5ото - aiylga ogoto), 'sun people' (күн киhumэ - kun kisite), 'people of sunrays with reins on their backs and with kind-hearted thoughts' (көхсүттэн тэһииннээх, көмүскэстээх санаалаах $к ү н$ сирин дьонноро - kohsutten mesiinneeh, komuskesteeh sanalaah kun sirin djonnoro) in their blessings - algys. The introduction of various signs and symbols that have a magical and protective function in traditional ritual types of clothing is explained primarily by the ancient mythological beliefs of the people. Among other types of ritual clothing, wedding clothing stands out for the variety of cuts and complexity of the decor, which has signs and symbols encoded within...") [3]. In this excerpt, Yakut folklore phrases emphasize that the craft is associated with ancient traditions and retains its unity with oral folklore and mythology to this day.

Thus, in the source material, the peculiarity of the Yakut style and the aesthetic tastes of the Yakuts which undoubtedly are a part of the culture - are implicitly presented via modeling of grammatical constructions. 


\section{Conclusion}

In our research, we have identified the description of the culture-specific elements of varying degrees of completeness and accuracy. In many already-established translation techniques, we can recognize the ways of describing a foreign language culture. Next, we question the wholeness of such descriptions in the translation text - in other words, the assessment of the appropriateness of introducing such additional parts into the translation text. Detection and research of specificity of describing Yakut culture in Russian allow forming recommendations for creating secondary texts. These secondary texts would provide insights into Yakut culture to the fullest extent possible for Russianspeaking people, including Russian-speaking Yakuts who do not know the Yakut language but want to know more about their native culture.

In our opinion, the most typical features and the most important points in the formation of translation strategies are the approaches of the authors of translated texts to the description of Yakut culture by means of the Russian language. The accuracy of the explanations, the depth of coverage, the elegance of the description - all are important in assessing the quality of translation. And the quality of translation determines not only the purity of the language, the artistic merit of the translation but also the accuracy of the conveyed ethnographic information.

When describing Yakut culture in Russian, there may be the following shortcomings. The first is transference of Yakut graphics into Russian text. The second is insufficient depth of description, or ignoring connotative information, symbolism, etc., which is obvious for a member of Yakut culture, and therefore does not require a special explanation, description, or commentary. The third is redundancy of additional information (commentaries) included in the translation text itself, i.e. the discrepancy between the amount of additional information and the goals of the translation.

According to our observations, when describing Yakut culture in translated texts by means of the Russian language as the target language, a unique "Yakut style", "olonkho style" is formed, which is distinct from other Russian translations of works of the peoples of the Russian Federation.

\section{References}

1. V.V. Kabakchi, Introduction into interlinguoculturology (Moscow, 2019)

2. Mighty Er Sogotoh: Yakut heroic epic (Novosibirsk, 1996)

3. S.I. Petrova, Yakut wedding dress: tradition and reconstruction (Novosibirsk, 2006)

4. Dalan, Remote Vilyui (Moscow, 1986)

5. A. Vasil'eva, J. of History Culture and Art Research. 7, 5 (2018) 